\title{
PSYCHOSOCIAL RISKS IN THE WORKPLACE: AN INCREASING CHALLENGE FOR GERMAN AND INTERNATIONAL HEALTH PROTECTION*
}

\author{
Roland PORTUNÉ \\ Berufsgenossenschaft für Rohstoffe und chemische Industrie, Heidelberg, Germany \\ Received in February 2012 \\ CrossChecked in May 2012 \\ Accepted in March 2012
}

\begin{abstract}
Occupational health in a changing world has to face up to psychosocial risks to protect the health of employees now and in the future. Faster production, service and communication processes, a service- and knowledge-based society, an increasing proportion of intellectual work, growing complexity of work-related demands, new technologies and constant availability, mobility demands, and job insecurity contribute to the problem of psychosocial risks in the workplace. Psychosocial risks affect both physical and psychosocial health. There is scientific evidence of the link between psychosocial work-related stress and cardiovascular diseases, affective disorders or musculoskeletal disorders, especially chronic back pain.

The Framework Directive on Safety and Health makes it very clear that employers are obliged "to ensure the safety and health of workers in every aspect relating to work". In spite of these far reaching obligations, a kind of taboo sometimes makes it hard to focus on topics that have psychosocial implications. A large number of models, instruments and methods are now available to gauge psychosocial risks in the workplace. Given the clear contrast between knowledge and application, there is not a lack of knowledge in this regard, but rather a lack of application.

In Germany, statutory accident insurance institutions are guided by two key principles: putting prevention before rehabilitation and rehabilitation before compensation. To prevent work-related health risks the BG RCI has developed several prevention tools to help employers and employees deal with psychosocial risks in the workplace.
\end{abstract}

KEY WORDS: affective disorders, cardiovascular diseases, musculoskeletal disorders, work-related stress

\section{Good old times and brave new world?}

Psychosocial risks in the workplace and the increasing challenge these present for health protection was not only the subject of intensive discussions at last year's MEDICHEM congress in Heidelberg, Germany, on 2-5 June 2011. In fact, experts all over

\footnotetext{
* Partly presented at the $39^{\text {th }}$ International MEDICHEM Congress on Occupational and Environmental Health in the Production and Use of Chemicals "Occupational Health in a Changing World", Heidelberg, Germany, 2 - 5 June 2011
}

the world agree that occupational health in a changing world has to face up to psychosocial risks to protect the health of employees now and in the future. An expert forecast by the European Agency for Safety and Health at Work identified emerging psychosocial risks, such as work intensification or high emotional demands at work (1). When comparing the working conditions of 20,50 or 100 years ago with the situation today, most people would also agree that psychosocial risks, such as time pressure, interruptions in the work 
flow or work-family conflicts, have increased. Nearly 50 percent of the 20,000 people in gainful employment selected on a representative basis in Germany indicated that "stress and work pressure" have increased. One in six even said that they "often had to work to the limits of their ability" (2).

When we compare our stressful times with the working conditions of the "good old days" we may sometimes wish we worked some 50 years ago. Nevertheless, we should be careful not to glorify the old times too much. In the "good old days", many accidents happened. Health protection was therefore there to save lives by preventing accidents. In Germany and in other parts of the world, we have been very successful in preventing accidents in recent decades. Today, the challenge of our time - and of the future seems to be the prevention of psychosocial risks.

Psychosocial risks in the workplace are sometimes called "soft factors". In a way, this description is suitable because there are indeed some difficulties in measuring them. There is no technical device that can be put into a factory or any kind of building indicating that there are "2,500 square meters of stress" or "four tons of mobbing". But most of us would agree that these so-called "soft factors" can have very hard implications.

\section{Essentials of this brave new world}

There are many parts to this problem. Some of the factors underlying psychosocial risks were dealt with at the European Union conference on "Promoting mental health and well being in workplaces" (3). In short, the conference summarised the following aspects that contribute to the problem of psychosocial risks in the workplace:

- Faster production, service and communication processes

- Increasing proportion of intellectual work

- Trend towards a service- and knowledge-based society

- Growing complexity of work-related demands

- New technologies and constant availability

- Mobility demands and job insecurity

- Instability in social relationships

If everything seems to be faster than before production, service and communication processes - it comes as no surprise that many people are shorter of breath in a psychosocial sense. If work-related demands appear to be more complex - and social and emotional demands form a core part of a wide variety of jobs these days - the health implications are consequently more complex as well.

If constant availability is a condition sine qua non, then the idea of going home and relaxing after work is becoming more and more of a pipedream. New technologies ensure we are available regardless of where we are. And just switching off the mobile phone could be a big mistake if we want to climb the career ladder or - more modestly - just want to keep our jobs. Following the rules of our time, we therefore all of a sudden have to move to another town - and once we feel settled, we might have to move to another, as flexibility seems to be the credo of this brave new world.

\section{Definition and facts: psychosocial risks affect both physical and psychosocial health}

The following definition describes psychosocial risks as "those aspects of work design and the organisation and management of work, and their social and environmental contexts, which have the potential for causing psychological or physical harm" (4).

Psychosocial risks affect both physical and psychosocial health. The link between psychosocial work-related stress and health problems has been a subject of global discussion since the early 1980s and has been proved using various work-related stress models. There is substantial evidence that psychosocial risks can lead to hypertension and cardiovascular diseases. The job strain model by Karasek and Theorell (5) as well as the effort-reward imbalance model by Siegrist (6) inspired a great amount of research that produced significant results highlighting the link between psychosocial risks and cardiovascular diseases.

High job demands combined with low job control must be considered a risky combination. Evidence has shown that there is a higher risk of becoming ill if a person's workload is high and there is little he/she can do to manage it effectively (7). The power of social support was integrated into this paradigm in the later stages of research (8). This showed that social support is a health resource - and that we are put at even greater risk if no social support is available.

Based on the effort-reward imbalance model, Siegrist (9) and other researchers showed that a socalled gratification crisis can also lead to a higher risk of cardiovascular diseases. Gratification crises emerge if we work hard and are committed - but no one seems to notice. Esteem is an important part of the salutogenic 


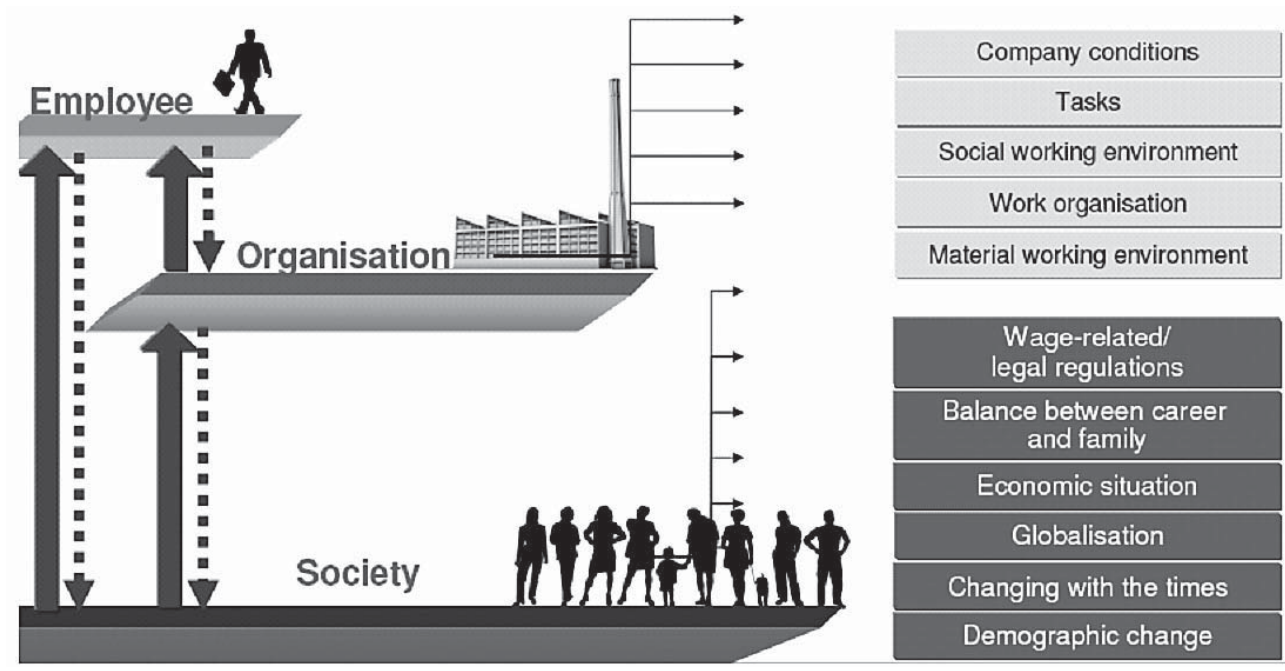

Figure 1 Three-level model of mental workload (19)

power of work. High effort combined with low reward is undoubtedly a serious risk.

There is therefore scientific evidence of the link between psychosocial work-related stress and cardiovascular diseases and affective disorders $(6,10)$. There is also a strong link between high work intensity, low job security, and a lack of social recognition on the one hand, and depression on the other (11). The increase in psychosocial risks at the workplace is closely linked with an increasing prevalence of mental disorders in Germany (12) and throughout Europe. In 2011, the BAUA (Bundesanstalt für Arbeitsschutz und Arbeitsmedizin) reported for Germany that 11.4 percent of sick leave days are due to mental disorders such as depression and anxiety. Of course, this increase does not derive solely from problems in the workplace, as mental health disorders usually develop from multifactorial causation. Nevertheless, psychosocial risks in the workplace often play an important part in the processes leading to anxiety, burnout or depression (13).

There is also a link - and a very complex relationship - between musculoskeletal disorders, especially chronic back pain, and psychosocial factors (14). There is also evidence of the impact of psychosocial factors, especially in later stages of the pain process. When forced to feel pain again and again, the power of catastrophising thoughts can be huge, activating the vicious circle of chronic pain and thereby leading to a close relationship between chronic pain and mood disorders such as depression.

The quality of scientific research into psychosocial risk and health has improved significantly in the last ten years (for example, comprehensive longitudinal studies, use of objective health indicators), to the extent that there is no longer any doubt as to the existence of a causal link between psychosocial workrelated stress and health $(15,16)$.

\section{Is working bad for your health? Is working good for your health?}

Can we therefore say that "working is bad for your health" today?

When asking this question, we must be careful to consider the health situation of the unemployed as well. In these cases, being out of work seems to be much worse than working (17). For example, Wacker \& Kolobkova (18) identified strong links between unemployment and health problems or negative selfesteem. Generally speaking, having a job seems to be consistently better for your health than not having a job, particularly in the long term (19) (Figure 1).

There is sufficient evidence to suggest that, under the right conditions, work can be good for your health in a number of ways (20). The right working environment lets people show what they are capable of and is therefore a positive factor (21). In a good working environment, employees are also given the resources they need, including organisational and social resources (20). Organisational resources include a variety of tasks, complete activities and opportunities for participation. Social resources include a good working environment, staff oriented management behaviour and social support.

It is also interesting to remember what Sigmund Freud said when asked what a healthy human being should be able to do. He answered: "To love and to 
work". In a similar vein, Alexander von Humboldt wrote that work was just as basic a need as eating and sleeping. Even today, working still has a high salutogenic potential. We therefore need to take a closer look at what factors have the potential to cause psychological or physical harm. But sadly, agreeing on this point does not necessarily translate into practice.

\section{A kind of taboo}

Occupational health and safety professionals from different companies agree that it is very important to deal with psychosocial risks in the workplace. On the other hand, the answers vary greatly. When asked how much emphasis is placed on psychosocial factors in the workplace, different companies seem to have different approaches - the majority pay little to medium attention to the topic while only a minority pay great attention to psychosocial risks in the workplace. Why is this?

As shown in the three-level model (22), interaction between the individual, the organisation and society is very complex. Individual thoughts and feelings have not yet been dealt with as key themes for occupational safety and health. Over time, most working people encounter some problems concerning some aspects of their working situation, but not all of them want to talk about these problems. This kind of taboo sometimes makes it hard to focus on topics that have psychosocial implications. Corporate decision-makers sometimes hope to get to grips with the topic with low-threshold measures based on the motto: "Wash me but please don't get me wet!" (23). Enterprises and employers who are not willing to deal with psychosocial risks argue that either the individual or society - or both - is the cause of the problem. This is correct in part, as long as the enterprise also admits to playing a crucial part in the mix. In this case, it is important to identify the psychosocial risks in the workplace and ask what can be done about them.

\section{The European perspective: Framework Directive on Safety and Health}

European legislation states that this is exactly what needs to be done. The Framework Directive on Safety and Health makes it very clear that employers are obliged "to ensure the safety and health of workers in every aspect relating to work".

The general principles of prevention aim to avoid risks or to evaluate risks that cannot be avoided, thereby combating the risks at source. "Developing a coherent overall prevention policy that covers technology, organisation of work, working conditions, social relationships, and the influence of factors relating to the working environment" - these are the far-reaching obligations that form the basis for a holistic health management system that goes far beyond individual training courses.

\section{Where and when to act?}

There's nothing wrong with seminars on stress management or communication. Studies show that cognitive-behavioural stress training is very effective and successful (24). The key is to take action on both
Where to act?

\begin{tabular}{l|l|l} 
& Preventive & Corrective \\
\hline Individual level & $\begin{array}{l}\text { Seminars on stress management } \\
\text { Communication training courses } \\
\text { Team training } \\
\text { Leadership training }\end{array}$ & $\begin{array}{l}\text { Dealing with (mental) } \\
\text { health disorders }\end{array}$ \\
\hline Organisational level & $\begin{array}{l}\text { Risk assessment on } \\
\text { psychosocial risks } \\
\text { Health management } \\
\text { Health policy/culture }\end{array}$ & $\begin{array}{l}\text { Rehabilitation } \\
\text { management }\end{array}$ \\
\hline
\end{tabular}

Figure 2 Where to act and when to act: preventive and corrective, on both individual and an organisational level (25). 


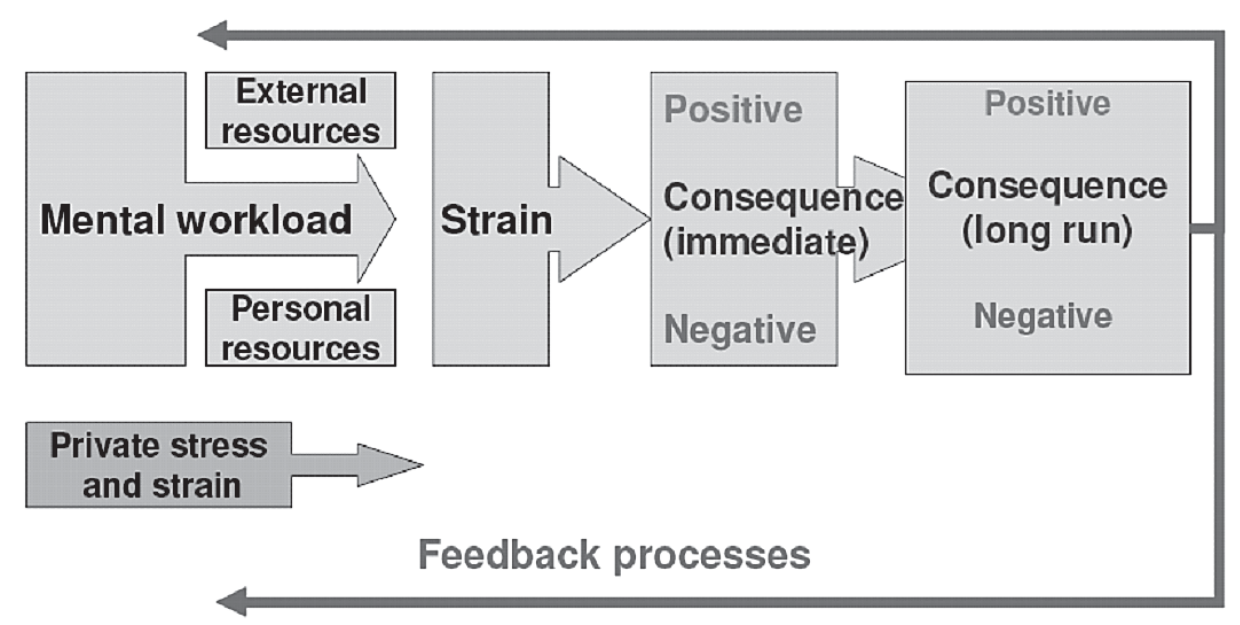

Figure 3 Mental workload and strain - DIN EN ISO 10075 (30)

individual and organisational level (25) (Figure 2). Risk assessments should form the starting point for systematic health management $(26,27)$. Preventive action is usually more effective and less cost-intensive than corrective action. Nevertheless, dealing with mental health disorders, especially systematic rehabilitation management, is an essential part of modern health protection. One step ahead of mental disorders are support systems provided by some firms enabling their employees to get in touch with psychological experts anonymously and in the strictest confidence. Today Employee Assistance Programs (EAP) have become common among many firms but no matter how effectively they may work - they can only be one part of the whole of the preventive approach as set out in the cited European legislation.

Knowing that risk assessment of psychosocial risks is both a legal obligation and a matter of management intelligence, it is interesting to take a look at how far we've come in Germany in integrating psychosocial risks in the risk assessment of occupational health and safety. A survey of works councils (28) showed that just 20 percent of larger businesses with a works council and at least 20 employees take into account psychological stress in their risk assessment. In the case of smaller businesses, a survey of owners showed that this figure is much lower, at just six percent (29).

Although traditional aspects of health and safety seem to be taken into account, psychosocial risks appear to have been largely forgotten or deliberately neglected.

What can be done? To overcome the aforementioned taboo, it is useful to take a closer look at how mental workload is defined and which aspects of the workload strain process should be factored into the risk assessments of modern workplaces.

\section{Mental workload and strain}

To achieve the essential aim of preventing health risks, mental workload factors must be analysed and evaluated alongside the humanised design of work.

Mental workload is defined in a European and an international ISO standard. Mental workload is described as "the sum of all assessable influences acting on a human from external sources and affecting it mentally" (DIN EN ISO 10 075-1).

According to this neutral and far-reaching definition of mental workload and its possible consequences, there can be both short-term and longterm consequences that can be either positive or negative (30) (Figure 3).

The advantage of this standardised model is that the psychosocial factors can be taken out of the "taboo zone" and we can explain both positive and negative outcomes. Nevertheless, possible causes of mental overload or underload and appropriate measures need to be addressed.

\section{What to do? Contributions of German Statutory Accident Insurance institutions}

Most employers must continue - or maybe even start - getting to grips with these demanding tasks. International organisations such as the World Health Organization (WHO) and the International Labour Organization (ILO) are trying to help $(31,32)$. In Germany, the Joint German Occupational Safety and 
Health Strategy ("Gemeinsame Deutsche Arbeitsschutzstrategie", GDA) is currently focusing on the challenging task of dealing with mental workload and psychosocial risks.

A large number of models, instruments and methods are now available to gauge psychosocial risks in the workplace (33-35). Given the clear contrast between knowledge and application, we can - and must - therefore no longer talk about a lack of knowledge in this regard, but rather a lack of application.

The "Berufsgenossenschaft für Rohstoffe und chemische Industrie" (BG RCI) is the Institution for Statutory Accident Insurance and Prevention for Raw Materials and the Chemical Industry in Germany. It is part of the comprehensive social security system in Germany. The Statutory Accident Insurance institutions in Germany are public-law bodies - institutions whose legal authority derives from public law ("Sozialgesetzbuch VII" (36) is a part of the German Social Code). They are different, for example, to private-law institutions such as associations. The legal basis for such institutions is the BGB (Civil Code).

Industrial institutions for statutory accident insurance and prevention have the statutory duty to prevent occupational accidents, occupational diseases and work-related health risks. We provide comprehensive assistance to companies in all occupational safety matters, train insured employees, investigate causes of accidents, and test technical equipment (37).

BG RCI insures 1.3 million employees and is responsible for 36,000 companies of various sizes. The three main tasks of statutory accident insurance institutions in Germany are:

1. To prevent accidents, occupational diseases and work-related health risks.

2. To treat and reintegrate victims of accidents or diseases.

3. To pay benefits in the event of a permanent reduction in earning capacity.

Statutory accident insurance institutions are guided by two key principles: putting prevention before rehabilitation and rehabilitation before compensation. To prevent work-related health risks, the BG RCI has developed several prevention tools to help employers and employees deal with psychosocial risks in the workplace.

In the field of adult education, the BG RCI offers large training centres at four locations where you can learn everything you need to know about health and safety, promotion of occupational health, explosion protection, machine and plant safety, personnel management, communication, and much more besides. Insured persons can attend a wide variety of seminars and workshops at attractive locations throughout Germany. Topics at these workshops and seminars include leadership, stress management, communication, moderation, working together, mobbing and mediation, risk assessment, and many others.

People can also specialise in psychological topics and work towards a certificate which they can obtain by attending a few psychological seminars and heading up an occupational project on psychosocial factors in their own enterprise. They are supported by occupational psychologists from the BG RCI. Qualified multipliers who improve prevention at their enterprises are another important piece of the puzzle. They are necessary if psychosocial risks are to be prevented in the workplace.

Last but not least, people can also ask for counselling to find the right strategy to deal with psychosocial risks in their own specific working environment. The BG RCI's psychologists are happy to help them find the right psychosocial solutions for the specific circumstances of their own enterprises.

\section{CONCLUSION}

In conclusion, when it comes to psychosocial risks in the workplace, I believe...

- enough is known - now we have to act.

- we have to focus on working conditions and the organisation and management of work in a social context.

- we need to act at organisational level, including systematic approaches to leadership, health and safety management and organisational development.

- we need interdisciplinary cooperation between psychological, medical and technical experts.

- we need to talk about our experiences and learn from one another.

\section{REFERENCES}

1. Roskamps N, Op De Beeck R, Pahkin K, Berthet M, Morvan E, Kuhn K, Kaluza S, Hupke M, Hauke A, Reinert D, Widerszal-Bazyl M, Bilbao JP, Oncins de Frutos M. Expert forecast on emerging psychosocial risks related to occupational 
safety and health. Luxembourg: European Agency for Safety and Health at Work. Office for Official Publications of the European Communities; 2007.

2. Hasselhorn HM. [Arbeit, Stress und Krankheit, in German]. In: Weber A, Hörmann G, editors. Psychosoziale Gesundheit im Beruf - Mensch - Arbeitswelt - Gesellschaft. Stuttgart: Gentner Verlag; 2007. p. 47-73.

3. European Union (EU). Conclusions and Recommendations for Action. From the perspective of the conference organisers of the EU Thematic Conference "Promoting mental health and well-being in workplaces". 3-4 March 2011, Berlin http://ec.europa.eu/health/mental_health/docs/ev_20110303_ concl en.pdf

4. Cox T, Griffith A, Rial-González E. Research on WorkRelated Stress. Luxembourg: Office for Official Publications of the European Communities; 2000.

5. Karasek RA, Theorell T. Healthy Work: Stress, Productivity and the Reconstruction of Working Life. New York (NY) Basic Books; 1990.

6. Siegrist J. [Medizinische Soziologie, in German]. München: Urban \& Fischer; 2005.

7. Collins SM, Karasek RA, Costas K. Job strain and autonomic indices of cardiovascular disease risk. Am J Ind Med 2005;48:182-93.

8. Demerouti E. [Das Arbeitsanforderungen-Arbeitsressourcen Modell von Burnout und Arbeitsengagement, in German] In: Psychische Belastung und Beanspruchung DIN, 51-60. Berlin: Deutsches Institut für Normung e.V.; 2010.

9. Siegrist J. Effort reward imbalance at work and cardiovascular diseases. Int J Occup Med Environ Health 2010;23:27985 .

10. Kivimäki M, Leino-Arjas P, Luukonen R, Riihimäki R, Vahtera J, Kirjonen J. Work stress and risk of cardiovascular mortalitiy: Prospective cohort study of industrial employees. Br Med J 2002;325:857-61.

11. Rösler U, Stephan U, Hoffmann K, Morling K, Müller A, Rau R. Psychosoziale Merkmale der Arbeit, Überforderungserleben und Depressivität [Psychosocial job characteristics, demands, and depressive mood, in German] Zeitschrift für Arbeits- und Organisationspsychologie 2008;52:191-203.

12. Schröder H, Macco K. [Steigender Krankenstand: Psychische Erkrankungen weiterhin auf dem Vormarsch, in German] Pressemitteilung des Wissenschaftlichen Instituts der AOK (WIdO). Berlin, 25. Februar 2009.

13. Rau R, Gebele N, Morling K, Rösler U. [Untersuchung arbeitsbedingter Ursachen für das Auftreten von depressiven Störungen, in Grman]. Forschung Projekt F 1865. Dortmund: Bundesanstalt für Arbeitsschutz und Arbeitsmedizin; 2010.

14. Zimolong B, Elke G, Bierhoff H-W. [Den Rücken stärken. Grundlagen und Programme der betrieblichen Gesundheitsförderung, in German]. Göttingen: Hogrefe; 2008 .

15. van Vegchel N, de Jonge J, Bosma H, Schaufeli W. Reviewing the effort-reward imbalance model: Drawing up the balance of 45 empirical studies. Soc Sci Med 2005;60:1117-31.

16. Hasselhorn H-M, Portuné R. [Stress, Arbeitsgestaltung und Gesundheit, in German]. In: Badura B, Walther U, Hehlmann T, editors. Betriebliche Gesundheitspolitik: Der Weg zur gesunden Organisation. Heidelberg: Springer; 2010. p. 36176.
17. Badura B. [Herausforderungen betrieblicher Gesundheitspolitik, in German]. In: Badura B, Walter U, Hehlmann T, editors. Betriebliche Gesundheitspolitik: Der Weg zur gesunden Organisation. 2. Auflage. Heidelberg: Springer; 2010. p. 11-7.

18. Wacker A, Kolobkova A. [Arbeitslosigkeit und Selbstkonzept - ein Beitrag zu einer kontroversen Diskussion, in German]. Zeitschrift für Arbeits- und Organisationspsychologie 2000;44:69-82.

19. Windemuth D. [Stress, in German]. In: Windemuth D, Jung D, Petermann O, editors. Praxishandbuch psychische Belastungen im Beruf. Vorbeugen. Erkennen. Handeln. Wiesbaden: Universum Verlag; 2010. p. 334-40.

20. Richter G. [Gesundheitsförderliche Aspekte der Arbeit, in German]. In: Windemuth D, Jung D, Petermann O, editors. Praxishandbuch psychische Belastungen im Beruf. Vorbeugen. Erkennen. Handeln. Wiesbaden: Universum Verlag; 2010. p. 13-5.

21. Pietrzyk U. [Zusammenhang zwischen Arbeit und Kompetenzerleben, in German]. Zeitschrift für Arbeits- und Organisationspsychologie 2001;45:2-14.

22. Windemuth D, Jung D, Petermann O. [Das Drei-Ebenenmodell psychischer Belastungen im Betrieb, in German]. In: Windemuth D, Jung D, Petermann O, editors. Praxishandbuch psychische Belastungen im Beruf. Vorbeugen. Erkennen. Handeln. Wiesbaden: Universum Verlag; 2010. p. 13-5.

23. Ludborzs B. [Psyche und Arbeitswelt - "Wasch mich aber mach mich bitte nicht nass" Zur Umsetzung fachpsychologischer Konzepte durch betriebliche Entscheidungsträger, in German]. Ergo-Med 2009;33:18893.

24. Semmer N, Zapf D. [Gesundheitsbezogene Interventionen in Organisationen, in German]. In Schuler H, editor. Organisationspsychologie. 2. Auflage. Göttingen: Hogrefe; 2004. p. 773-843.

25. Portuné R. [Zwischen Kür und Knochenarbeit. Psychosoziale Aspekte und Gesundheit im Arbeitsleben, in German]. In: Ludborzs B, Nold H, editors. Psychologie der Arbeitssicherheit und Gesundheit. Entwicklungen und Visionen. Heidelberg, Kröning: Asanger Verlag; 2009. p. 234-52.

26. Ulich E, Wülser M. [Gesundheitsmanagement in Unternehmen. Arbeitspsychologische Perspektiven, in German]. 3. Auflage. Wiesbaden: Gabler; 2009.

27. Pferdmenges U, Lemm J, Portuné R. [Gesunde Finanzverwaltung NRW. Ein effizientes Gesundheitsmanagementsystem als Investition in die Zukunft, in German]. Ergo-Med 2010;34:172-5.

28. Ahlers E. [Belastungen am Arbeitsplatz und betrieblicher Gesundheitsschutz vor dem Hintergrund des demographischen Wandels. Ergebnisse der PARGEMA / WSI Betriebsrätebefragung 2008/2009. WSI Diskussionspapier 175, in German]. Düsseldorf: Wirtschafts- und sozialwissenschaftliches Institut der Hans-Böckler-Stiftung; 2011.

29. Szesny C, Keindorf S, Droß P. [Untersuchung zum Kenntnisstand von Unternehmern und Beschäftigten auf dem Gebiet des Arbeits- und Gesundheitsschutzes in KMU (F 1913), in German]. Teil 1 des 2. Zwischenberichts an die BAuA. Ergebnisse der Befragung von Inhaber/innen / Geschäftsführer/innen. Unveröffentlichter Bericht an die BAuA. 2010. 
30. Nachreiner F. [Entwicklung und aktuelle Bedeutung der Normenreihe, in German]. DIN EN ISO 10075. In: Psychische Belastung und Beanspruchung. Berlin: Deutsches Institut für Normung e.V.; 2010. DIN, 7-15.

31. Leka S, Jain A. Health Impact of Psychosocial Hazards at Work: An Overview. Geneva; WHO; 2010.

32. Forastieri V. ILO Approach to Mental Health and Well-Being at Work [displayed 21 May 2012]. Available at http://ec. europa.eu/health/mental_health/docs/ev_20110303_co53_ en.pdf

33. Resch M. [Analyse psychischer Belastungen - Verfahren und ihre Anwendung im Arbeits- und Gesundheitsschutz, in German]. Bern: Huber; 2003.

34. Richter G. [Erfassung psychischer Belastung im Betrieb und psychologische Arbeitsgestaltung: Rückblick, Situationsanalyse, Ausblick, in German]. In: Ludborzs B, Nold H, editors. Psychologie der Arbeitssicherheit und
Gesundheit. Entwicklungen und Visionen. Heidelberg: Asanger Verlag; 2009. p. 253-65.

35. Nebel C, Wolf S, Richter P. [Instrumente und Methoden zur Messung psychischer Belastung, in German]. In: Windemuth D, Jung D, Petermann O, editors. Praxishandbuch psychische Belastungen im Beruf. Vorbeugen. Erkennen. Handeln. Wiesbaden: Universum Verlag; 2010. p. 261-74.

36. Ein Service des Bundesministeriums der Justiz in Zusammenarbeit mit der juris $\mathrm{GmbH}$ - www.juris.de. [Siebtes Buch Sozialgesetzbuch - Gesetzliche Unfallversicherung (Artikel 1 des Gesetzes vom 7. August 1996, BGBl. I S. 1254), das zuletzt durch Artikel 15 Abs. 98 des Gesetzes vom 5. Februar 2009 (BGB1. I S. 160) geändert worden ist. SGB 7, in German] [displayed 21 May 2012]. Available at http:// www.hus-neumuenster.com/sgb/sgb7.pdf

37. Berufsgenossenschaft für Rohstoffe und chemische Industrie (BG RCI). Working Together to Enhance Future Performance. Heidelberg: BG RCI Flyer; 2011. 


\section{Sažetak}

\section{PSIHOSOCIJALNI RIZICI NA RADNOM MJESTU: RASTUĆI IZAZOV ZAŠTITE ZDRAVLJA U NJEMAČKOJ I SVIJETU}

Moderna medicina rada mora se suočiti s psihosocijalnim rizicima kako bi se sada i ubuduće zaštitilo zdravlje radnika. Brža proizvodnja, uslužni i komunikacijski procesi, društvo koje se temelji na uslugama i znanju, veći intelektualni napor, rastuća složenost zahtjeva povezanih s radom, novi tehnološki postupci, stalna raspoloživost, zahtjevi mobilnosti i nesigurnost posla doprinose psihosocijalnim opasnostima na radnom mjestu. Postoje znanstveni dokazi koji idu u prilog povezanosti radnoga psihosocijalnog stresa i afektivnih ili mišićno-koštanih poremećaja, a naročito kroničnih bolova u leđima.

U okvirnoj Direktivi o sigurnosti i zdravlju izrijekom se navodi da poslodavci imaju obvezu "zajamčiti sigurnost i zdravlje radnika u svim radnim aspektima". Unatoč takvim dalekosežnim obvezama postoje određeni tabui zbog kojih se ponekad teško usredotočiti na teme koje imaju psihosocijalne implikacije. Postoji veliki broj modela, instrumenata i metoda kojima se u današnje vrijeme mogu mjeriti radni psihosocijalni rizici. S obzirom na to da postoji jasna razlika između samog znanja i njegove primjene, možemo reći da u ovom smislu ne nedostaje znanje, već primjena postojećega znanja.

Njemačke državne osiguravajuće kuće slijede dva ključna načela: stavljaju sprječavanje ispred rehabilitacije, a rehabilitaciju ispred kompenzacije. Kako bi se spriječili radni zdravstveni rizici, njemačka državna osiguravajuća ustanova za sirovine i kemijsku industriju (BG RCI) osmislila je nekoliko preventivnih mjera kojima nastoji pomoći poslodavcima i zaposlenicima u suočavanju s psihosocijalnim rizicima na radnom mjestu.

KLJUČNE RIJEČI: afektivni poremećaji, kardiovaskularne bolesti, mišićno-koštani poremećaji, stres na radu

\section{CORRESPONDING AUTHOR:}

Roland Portuné, Dipl.-Psych.

BG RCI, Kurfürsten-Anlage 62, 69115 Heidelberg, Germany E-mail: roland.portune@bgrci.de 